\title{
Sugarcane yield estimation for climatic conditions in the center of state of Goiás
}

\author{
Jordana Moura Caetano $^{1 *}$, Derblai Casaroli $^{1}$ \\ 10.1590/0034-737X201764030011
}

\begin{abstract}
Models that estimate potential and depleted crop yield according to climatic variable enable the crop planning and production quantification for a specific region. Therefore, the objective of this study was to compare methods to sugarcane yield estimates grown in the climatic condition in the central part of Goiás, Brazil. So, Agroecological Zone Method (ZAE) and the model proposed by Scarpari (S) were correlated with real data of sugarcane yield from an experimental area, located in Santo Antônio de Goiás, state of Goiás, Brazil. Data yield refer to the crops of 2008/2009 (sugarcane plant), 2009/2010, 2010/2011 and 2011/2012 (ratoon sugarcane). Yield rates were calculated as a function of atmospheric water demand and water deficit in the area under study. Real and estimated yields were adjusted in function of productivity loss due to cutting stage of sugarcane, using an average reduction in productivity observed in the experimental area and the average reduction in the state of Goiás. The results indicated that the ZAE method, considering the water deficit, displayed good yield estimates for cane-plant $(\mathrm{d}>0.90)$. Water deficit decreased the yield rates $(r=-0.8636 ; \alpha=0.05)$ while the thermal sum increased that rate for all evaluated harvests $(r>0.68 ; \alpha=0.05)$.
\end{abstract}

Key words: agricultural planning; Saccharum spp.; yield prediction model.

\section{RESUMO}

\section{Estimativa da produtividade agrícola da cana-de-açúcar para as condições climáticas do Centro Goiano}

Modelos que estimam a produtividade potencial e deplecionada dos cultivos agrícolas em função de variáveis climáticas tornam possível o planejamento agrícola da lavoura e a quantificação da produção para uma dada região. Sendo assim, objetivou-se comparar métodos para a estimativa da produtividade da cana-de-açúcar cultivada nas condições climáticas da região central do Estado de Goiás. Para isto, utilizaram-se o Método da Zona Agroecológica (ZAE) e o modelo proposto por Scarpari (S), correlacionando-os aos dados reais de produtividade da cana, em uma área experimental, localizada em Santo Antônio de Goiás GO. Os dados de produtividade são referentes aos anos safra 2008/2009 (cana-planta), 2009/2010, 2010/2011 e 2011/2012 (canas-soca). Foram avaliadas também as taxas de produtividade em função da demanda hídrica atmosférica e do déficit hídrico da região de estudo. As produtividades estimadas e reais foram ajustadas em função da quebra de produtividade devido ao estádio de corte da cana, utilizando-se a redução de produtividade média observada na área experimental e a redução média para o estado de Goiás. Os resultados indicaram que a metodologia ZAE considerando o déficit hídrico apresentou boas estimativas de produtividade para a cana-planta $(\mathrm{d}>0,90)$. O déficit hídrico ocasiona redução na taxa de produtividade $(\mathrm{r}=0,8636, \alpha=0,05)$, enquanto a soma térmica contribui para o aumento dessa taxa em todas as safras avaliadas $(r>0,68, \alpha=0,05)$.

Palavras-chave: Saccharum spp.; planejamento agrícola; modelo de previsão de produtividade.

\footnotetext{
Submitted on June $4^{\text {th }}, 2015$ and accepted on April 17 th, 2017.

${ }^{1}$ Universidade Federal de Goiás, Departamento de Agronomia, Goiânia, Goiás, Brazil. jordanamcaetano@gmail.com; derblai@ufg.br

*Corresponding author: jordanamcaetano@gmail.com
} 


\section{INTRODUCTION}

Estimation of productivity makes it possible to obtain strategic information that benefits sugar and alcohol companies, from which they optimize their operational programming with regard to the ideal cutting season and the agricultural planning of the sugarcane crop, which is a very important factor for the optimization of profitability of the project (Scarpari \& Beauclair, 2004). The government is also favored with productivity prediction since it uses the crop edaphoclimatic zoning to minimize loss risk in the bank financing system (Rossetti, 2001).

Sugarcane productivity depends, among other factors, on the interactions between climate variations and their phenological phases. Water stress causes a reduction in carbon dioxide assimilation rates, in leaf area size, in transpiration and growth rate, in plant water potential and stomatal opening (Rao et al., 2005; Gouvêa, 2008), in addition to a decrease in the stalk final height of sugarcane (Batista et al., 2015). Temperature is another extremely important climatic element in the production of sugarcane, acting directly on the maturation process, in which the plants respond to the thermal amplitude for the change from vegetative to reproductive stage (Doorenbos \& Kassam, 1979).

The Cerrado region of central-western Brazil has severe water deficit conditions between April and September, in addition to high daily temperatures, and may be the target of important studies that describe the behavior of sugarcane under these conditions.

From the productvity estimate models based on climatic elements and climatic factors, it is possible to predict possible crop failures and/or maximum possible productivity as well as to advance the studies on the influence of climatic extremes on crop productivity (Oliveira et al., 2012).

Among the models of productivity prediction, the Agroecological Zone Method (Doorenbos \& Kassam, 1979), which, in general, estimates the potential productivity of agricultural crops by assuming that the water and nutritional needs are satisfactorily met. However, it does not account the losses caused by attack of pests and or diseases (Barbieri \& Silva, 2008). On the other hand, potential productivity can be penalized acording to the water deficit (Gouvêa et al., 2009). The best estimates of sugarcane productivity are obtained when this model is adjusted and calibrated for the local climatic conditions (Barbieri \& Silva, 2008; Oliveira et al., 2012). Other models have also been described to estimate sugarcane productivity for local conditions (Scarpari, 2002; Marin et al., 2008; Cuadra et al., 2012), emphasizing the model proposed by Scarpari (2002), which because working with the variables rainfall and air temperature is a good alternative to predict sugarcane productivity in the climatic conditions of Cerrado in the Center-West of Brazil.

The objective of this study was to compare methods for estimating sugarcane yield under the climatic conditions of the central region of the State of Goiás.

\section{MATERIAL AND METHODS}

Sugarcane yields were obtained in an experimental area located in the municipality of Santo Antônio de Goiás, state of Goiás (16² 29' 8" S; 49²0' 36"; 780 m above sea level), for the harvests of 2008/2009 (sugarcane plant), 2009/ 2010, 2010/2011 and 2011/2012 (ratoon sugarcane). The variety of sugarcane cultivated in the area was CTC-4.

The experiment was carried out in a medium textured, dystrophic Red-Yellow Latosol (270 $\mathrm{g} \mathrm{kg}^{-1}$ clay, $130 \mathrm{~g} \mathrm{~kg}^{-}$ ${ }^{1}$ silt and $600 \mathrm{~g} \mathrm{~kg}^{-1}$ sand). The soil was plowed and harrowed and $2.0 \mathrm{t} \mathrm{ha}^{-1}$ of agricultural gypsum and $4.0 \mathrm{t}$ $\mathrm{ha}^{-1}$ of limestone were applied for soil correction. At planting, $120 \mathrm{~kg} \mathrm{ha}^{-1}$ of $\mathrm{P}_{2} \mathrm{O}_{5}$ were applied and $380 \mathrm{~kg} \mathrm{ha}^{-1}$ of the 18-00-27 (N-P-K) formulated was applied in topdressing. Weeds were controlled with the application of hexazinone, diurom, isoxaflutole, tebutiuron and isoxaflutole, at the amounts recommended by the manufacturer.

The experiment used two models of sugar cane yield estimates:

i) Agro ecological zone method (ZAE) or FAO Model (Doorenbos \& Kassam, 1979):

$\mathrm{PP}=\mathrm{PPB}_{\mathrm{P}} \cdot \mathrm{C}_{\mathrm{IAF}} \cdot \mathrm{C}_{\mathrm{R}} \cdot \mathrm{C}_{\mathrm{C}} \cdot \mathrm{C}_{\mathrm{MO}} \cdot \mathrm{N}_{\mathrm{D}}$

In that PP is the potential productivity $(\mathrm{kg} \mathrm{MS} \mathrm{ha-1}$ day $\left.{ }^{-1}\right), \mathrm{PPB}_{\mathrm{P}}$ is the gross photosynthetic production of a standard crop dry matter $\left(\mathrm{kg} \mathrm{DM} \mathrm{ha-1} \mathrm{d}^{-1}\right) ; \mathrm{C}_{\mathrm{IAF}}$ is the correction for the existing leaf area index (whether IAF < 5 , then $\mathrm{C}_{\mathrm{IAF}}=0.0093+0.185 \mathrm{LAI}-0.0175 \mathrm{IAF}^{2}$, but whether IAF e" 5 , then $\left.C_{I A F}=0.5\right) ; C_{R}$ is the correction for the crop maintenance rate, using $C_{R}=0.6$ for $T<20^{\circ} \mathrm{C}$ and $C_{R}=0.5$ for $\mathrm{T} \mathrm{e} " 20{ }^{\circ} \mathrm{C} ; \mathrm{C}_{\mathrm{C}}$ is the correction for the harvested part of such crop (Harvest Index), using $\mathrm{C}_{\mathrm{C}}=0.75$ for sugar cane; $\mathrm{C}_{\mathrm{MO}}$ is the correction of residual moisture in the dry matter of the profitable part $\left(\mathrm{C}_{\mathrm{MO}}\right.$ sugar cane $\left.=0.8\right)$; and $\mathrm{N}_{\mathrm{D}}$ is the number of days of the total period of the crop cycle. The daily rate of the potential productivity was obtained by the relationship between the potential productivity of the month and the number of days of the month in question. The depleted productivity, that is, when the real productivity ( $\mathrm{RP}, \mathrm{kg} \mathrm{ha}^{-1} \mathrm{day}^{-1}$ ) ceases to be potential (RP < PP) due to the water deficit, was estimated by equation 2 :

$\mathrm{RP}=\mathrm{PP} \cdot\left[1-\mathrm{k}_{\mathrm{y}} \cdot\left(1-\frac{\mathrm{ETa}}{\mathrm{ETo}}\right)\right]$ 
Where $\mathrm{k}_{\mathrm{y}}$ is the sensitivity factor to crop water deficit, at each growth stage (budding, establishment and vegetative growth: 0.75 , harvest formation: 0.5 , maturation: $0.1)$, ETa is the actual evapotranspiration $\left(\mathrm{mm} \mathrm{day}^{-1}\right)$, and ETo is the reference evapotranspiration $\left(\mathrm{mm} \mathrm{day}^{-1}\right)$, set by the method of Thornthwaite (1948).

ii) Scarpari (2002): model that regards rain and air temperature

$\mathrm{TSH}=35.72306+0.57487 . \mathrm{mm} 1+0.22957 . \mathrm{mm} 2+0.29839$

$. \mathrm{mm} 4+0.89310 . \mathrm{mm} 5-0.34098 . \mathrm{Gd} 4$

$\mathrm{TSH}=64.21145+0.27273 . \mathrm{mm} 4$

Where TSH are the tonnes of stalk per hectare, $\mathrm{mm}_{\mathrm{n}}$ is the precipitation of the " $\mathrm{n}$ "th" month before plot harvesting $(\mathrm{mm})$, and $\mathrm{Gd}_{\mathrm{n}}$ are the degree days in the " $\mathrm{n}$ th" month prior to harvest $\left({ }^{\circ} \mathrm{C}\right)$. Degree-days $\left(\mathrm{Gd},{ }^{\circ} \mathrm{C}\right.$-day) vary according to the average air temperature and the crop base temperature (Equations 5 and 6):

For $\mathrm{TM}>\mathrm{Tb}>\mathrm{Tm}$ :

$\mathrm{Gd}=\frac{\mathrm{TM}-\mathrm{Tb}^{2}+(\mathrm{TM}-25)^{2}}{2 \cdot(\mathrm{TM}-\mathrm{Tm})} \cdot \mathrm{f} . \mathrm{NDM}$

And for $\mathrm{Tb}<\mathrm{Tm}$ :

$\mathrm{Gd}=\mathrm{Tm}-\mathrm{Tb}+\frac{(\mathrm{TM}-\mathrm{Tm})}{2}+\frac{(\mathrm{TM}-25)^{2}}{2 \cdot(\mathrm{TM}-\mathrm{Tm})} \cdot \mathrm{f} . \mathrm{NDM}$

Where TM and Tm are the maximum and minimum monthly temperatures $\left({ }^{\circ} \mathrm{C}\right)$, respectively; $\mathrm{Tb}$ is the sugar cane base temperature, $\mathrm{Tb}=20^{\circ} \mathrm{C}$ (Barbieri et al., 1979); $\mathrm{f}$ is a function factor of the photoperiod ( $\mathrm{N}$, hours), set by equation 7 :

$\mathrm{f}=\left(\frac{\mathrm{N}}{24}-\mathrm{N}\right)^{2}$

And NDM is the number of days of the month. The climatic variables, air temperature, relative air humidity, solar radiation, radiation balance, wind velocity and rainfall used in the models were provided by EmbrapaArroz e Feijão automatic weather station (Santo Antônio de Goiás, Goiás state).

The daily sequential water balance (Thornthwaite \& Mather, 1955), with adjustments in the CAD (available water capacity) was applied, using a value equal to 78 $\mathrm{mm}$, rather than the one recommended by the authors, for the group of large crops $(\mathrm{CAD}=100 \mathrm{~mm})$. For this adjustment, a preliminary study described the effective depth of the sugarcane average root system $(\mathrm{Ze}=0.50 \mathrm{~m})$ and the physical-water characteristics of the soil, in the area under study.

For correlation effects, gross data provided by the models as well as the adjusted data were used because of the productivity losses as a function of the number of cuts in each study area (plot), as well as the data adjusted by the average decrease in productivity in the state of Góias were used. The average sugarcane yield data in Goiás were obtained from the Conab website (2014).

The productivity reduction, both in the experimental area and in the state of Goiás, was estimated from the ratio between the productivity $\left(\mathrm{t} \mathrm{ha}^{-1}\right)$ of the " $\mathrm{n}$ "th" cut $\left(\mathrm{P}_{\mathrm{n}}\right)$ and the $1^{\text {st }}$ cut $\left(\mathrm{P}^{1 \mathrm{st}}\right)$.

The performance of the models was tested from the coefficient of determination $\left(\mathrm{R}^{2}\right)$, root mean squared error (RMSE), mean absolute error (MAE) and Willmott's concordance index (d).

\section{RESULTS AND DISCUSSION}

In relation to the cuts for the state of Goiás, sugarcane yields show productivity declines from the second cut for all harvest years as published by Conab (2014) in 2007/ 08 to $2011 / 12$ crops. The productivity losses were numerically higher as the number of cuts increased, complemented with a greater variation in productivity, as observed by the standard deviation. Physiologically, it is known that sugar cane ratoon productivity tends to decrease gradually as cutting stages are increased (Rodrigues, 1995).

The productivity of the experimental area followed the same tendency of the average yields presented in the same harvest years for the state of Goiás, with productivity losses during the cuts. However, the absolute values of the losses in the experimental area were as many as twice as those found for the state of Goiás.

By applying ZAE and Scarpari models (2002), and their respective adaptations according to the water deficit and the reduction in the sugar cane productivity due to the number of cuts for the state of Goiás (Conab, 2014) and the loss observed in the experimental area (Table 1), it was possible to verify that all the models presented high positive correlations in relation to the observed real values ( $r>0.95)$, in which the ZAE model can be highlighted, considering both the productivity decrease of the experimental area $\left(\mathrm{ZAE}_{2}\right)$ as well as the sum of the loss due to the water deficit and the decrease in the productivity of the area $\left(\mathrm{ZAE}_{\mathrm{d} 2}\right)$, which showed values of $\mathrm{r}=0.99$ (Table $1)$. These correlations reinforce the trend of decreasing in the productivity in function of the cuts observed in real values.

In the second and third sugar cane cuts, the model that presented the closest results to the real productivity was that proposed by Scarpari (2002), weighted by the loss due to the cuts referring to the state of Goiás. The model ZAE, corrected by the loss due to cuts referring the experimental area, approached the real productivity in the fourth cut. The values overestimated by the ZAE and $\mathrm{ZAE}_{\mathrm{d}}$ method can be justified since this model considers that the results represent a first-cut sugarcane in an ideal 
soil, free of pests and diseases, where losses only occur as a function of the climatic variables and water shortage, when that is the case (Table 1).

According to Teramoto (2003), this model is not ideal for productivity estimates at regional levels or smaller scales for sugarcane because ZAE model was developed to be used at a continental scale with contrasting regional climatic differences. In order to be used locally for sugarcane, this method must be adjusted from parameters and definitions of calculation intervals with experimental data. This is partially corroborated by the values obtained from the ZAE and $\mathrm{ZAE}_{\mathrm{d}}$ method when corrected due to losses from cuts, from which the overestimation of productivity data were reduced.

The methodology for estimation of potential productivity proposed by Scarpari (2002) considers the climatic variables, rainfall and air temperature, such as degree-days and negative degree-days besides presenting different models for cane-plant and ratoon cane. In addition, this method was developed for climatic conditions of a mesoregion, which may have contributed to a lower overestimation of ratoon sugarcane productivity when compared to the results obtained by ZAE and $\mathrm{ZAE}_{\mathrm{d}}$ models (considering water deficit). However, cane-plant productivity presented the greatest amplitude among all investigated models, inferring that this model was not well fit for the conditions of this study.

Sugarcane productivities estimated by the model proposed by Scarpari (2002) showed coefficient $d>0.80$ (Figure 1). However, the estimated values tended to overestimate, when the model without adequations and with adequacies due to the decrease in the productivity was applied in the experimental area (Figures 1A and 1B), and to underestimate when the adequacy of the average productivity loss in the state of Goiás (Figure 1B) was made. This occurred mainly for the highest values of caneplant productivity.

Moreover, the model proposed by Scarpari (2002), because of the lower adjustment for cane-plant productivity, provided an increase in errors, resulting in higher values of RMSE and MAE, which were in some cases approximately $100 \%$ of the observed real productivity (Table 1 ). The ZAE method showed better adjustment than the Scarpari (2002) methodology, presenting lower RMSE and MAE values (Figure 1). The best adjustment of this model may have occurred as it did not result in an overestimation of productivity for cane-plant, as expressive as the previous one. Nevertheless, the values obtained from both errors are still considered high.

Still in Figure 1, it was observed a good adjustment of the $\mathrm{ZAE}_{\mathrm{d}}$ method to the observed data $(\mathrm{d}>0.9)$, showing reductions in the RMSE and MAE values, when the loses due to the cutting stage $\left(<20 \mathrm{tha}^{-1}\right)$ were inserted in the estimation. The best adjustment of this method, when compared to the others, can be explained by the fact that the estimated productivity of the cane plant was the one that most approached the observed value and also, the values estimated in this study are corrected by the loss due to the water deficit, which also reduces the overestimation of the results. For this analysis, the ideal thing to do would be to investigate the estimated and observed productivity values of cane plant separately from ratoon cane, as it was done in the analysis of Table 1, where the best results were observed in the second and third cuts. However, a historical series of productivity observed in the experimental area for sugarcane plant would be necessary in order to be able to perform the regression analysis of the crop cycles (sugarcane plant and ratoon) separately.

Oliveira et al. (2012) tested the ZAE method for the macro-region of Triângulo Mineiro for yield data of cane plant and first-cut ratoon cane, separately, observing a better adjustment of the model for the estimated values of cane-plant, of which presented an overestimation of $1 \mathrm{tha}$ ${ }^{1}$, and this overestimation for ratoon cane was $5.9 \mathrm{t} \mathrm{ha}^{-1}$.

Carvalho (2009) calibrated the ZAE method for estimation of potential and real productivities for ratoon sugarcane, as a function of meteorological data and water availability in soils in the State of São Paulo from 1990/

Table 1: Sugarcane estimated productivity by the Scarpari (S) model, Agroecological Zone method (ZAE) and ZAE method considering water deficit $\left(\mathrm{ZAE}_{\mathrm{d}}\right)$, and their respective corrections as a function of the loss for the state of Goiás (1) and of the loos observed in the experimental area (2), as well as the productivity observed in the experimental area $\left(\mathrm{P}_{\mathrm{O}}\right)$ and its simple Pearson (r) correlations with the other models. Santo Antônio de Goiás, state of Goiás

\begin{tabular}{|c|c|c|c|c|c|c|c|c|c|c|}
\hline \multirow{2}{*}{ CUT } & \multicolumn{9}{|c|}{ ESTIMATED PRODUCTIVITY $\left(\mathrm{t} \mathrm{ha}^{-1}\right)$} & \multirow{2}{*}{$P_{0}\left(t h^{-1}\right)$} \\
\hline & $\mathbf{S}$ & $S_{1}$ & $\mathbf{S}_{2}$ & ZAE & $\mathrm{ZAE}_{1}$ & $\mathbf{Z A E}_{2}$ & $\mathbf{Z A E}_{\mathrm{d}}$ & $\mathbf{Z A E}_{\mathrm{d} 1}$ & $\mathbf{Z A E}_{\mathrm{d} 2}$ & \\
\hline $1^{\circ}$ & 239.6 & 239.6 & 239.6 & 157.7 & 157.7 & 157.7 & 128.9 & 128.9 & 128.9 & 112.8 \\
\hline $2^{o}$ & 64.27 & 52.94 & 28.30 & 86.44 & 71.21 & 38.07 & 91.85 & 75.67 & 40.45 & 49.65 \\
\hline $3^{\circ}$ & 64.43 & 49.57 & 29.66 & 96.42 & 74.19 & 44.38 & 82.52 & 63.49 & 37.99 & 51.90 \\
\hline $4^{\circ}$ & 78.94 & 58.98 & 23.77 & 90.12 & 67.34 & 27.14 & 86.96 & 64.98 & 26.18 & 33.95 \\
\hline Means & 111.8 & 100.3 & 80.33 & 107.7 & 92.62 & 66.83 & 97.56 & 83.26 & 58.38 & 62.06 \\
\hline$r$ & 0.95 & 0.96 & 0.98 & 0.97 & 0.98 & 0.99 & 0.95 & 0.97 & 0.99 & - \\
\hline
\end{tabular}



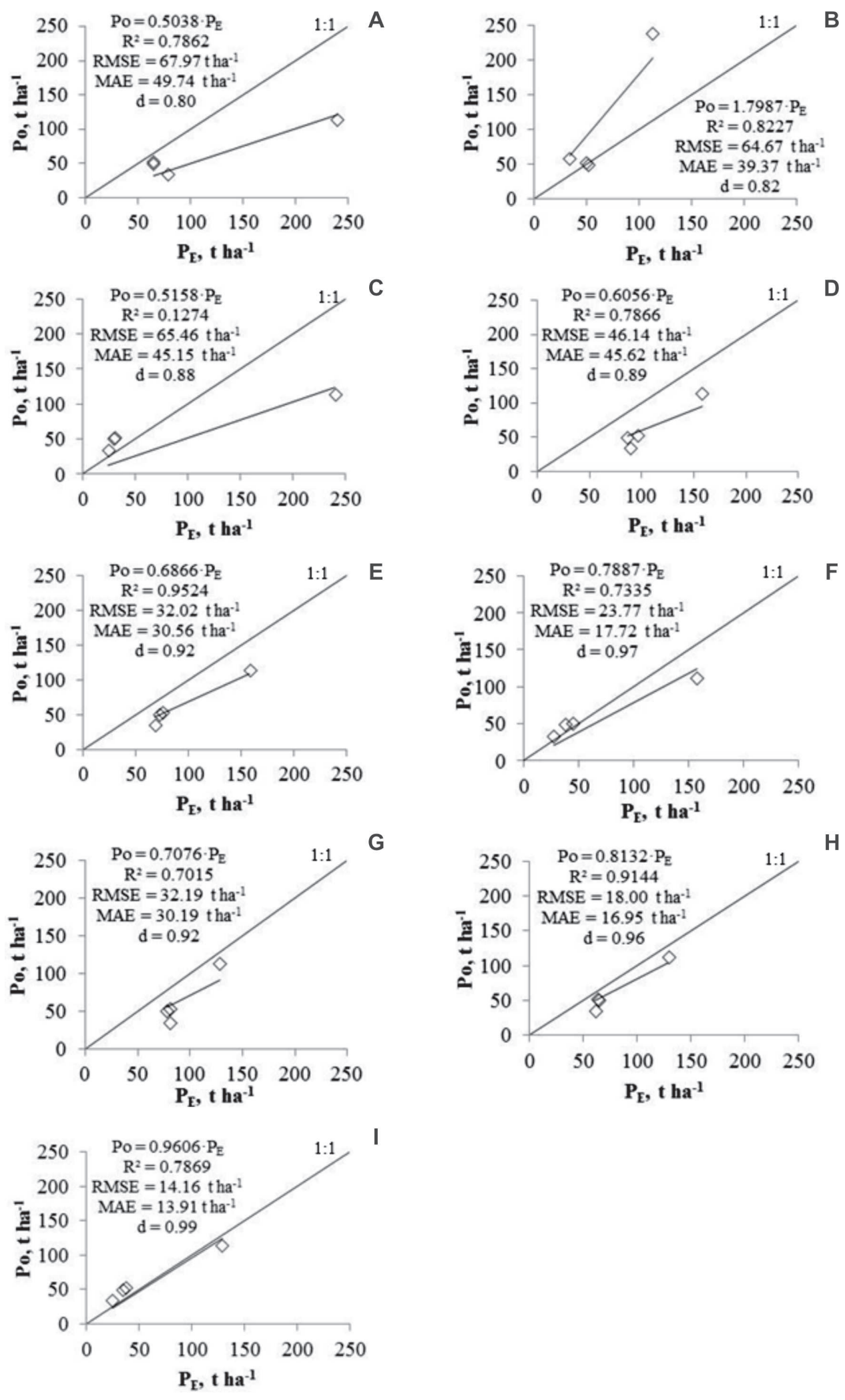

Figure 1: The relationship between the observed $\left(\mathrm{P}_{\mathrm{O}}\right)$ and the estimated $\left(\mathrm{P}_{\mathrm{E}}\right)$ productivities by the Scarpari method (A), Scarpari method according to the decrease in productivity in the state of Goiás (B), Scarpari method according to the productivity loss in the experimental area (C), Agroecological Zone method (D), Agroecological Zone method as a function of productivity loss in the state of Goiás (E), Agroecological Zone method as a function of productivity loss in the experimental area (F), ZAE method considering water deficit (G), ZAE method considering water deficit as a function of the productivity loss in the state of Goiás (H) and ZAE method considering water deficit as a function of the productivity loss in the experimental area (I) for the cane-plant cycle and first, second and third ratoon cane cycles, with their respective regression equations, coefficient of determination $\left(\mathrm{R}^{2}\right)$, root mean squared error (RMSE), mean absolute error (MAE), and Willmott's index of agreement (d). Santo Antônio de Goiás, state of Goiás. 
1991 to 2005/2006 harvests, obtaining a value of $R^{2}=0.60$. In order to assist the visualization of the period when the crop is more sensitive to water deficit, the water balance (water surplus [EXC] and water deficit [DEF]) were plotted under the curve that reflects the relationship between actual evapotranspiration (ETa) and reference evapotranspiration (ETo). Values of ETa/ETo $<1.0$ indicate that the soil-plant system was not able to supply the atmospheric water demand, being possible to verify periods of water restriction (Blain et al., 2009). In this study, values of ETa/ ETo $<1.0$ were observed in periods of water deficit (dry season), as shown in Figure 2.
Some studies correlate the ETa/ETo values to the production of crops such as: soybean (Moraes et al., 1998), marandu grass (Cruz et al., 2011), Tanzania grass (Pezzopane et al., 2012) as well as the model described by FAO (Doorenbos \& Kassam, 1979).

The values of the potential sugarcane productivities obtained by the ZAE method considering the water deficit for the 2008/2009 ( $1^{\text {st }}$ cut $), 2009 / 2010$ ( $2^{\text {nd }} \mathrm{crop}$ ), 2010/2011 ( $3^{\text {rd }}$ crop) and 2011/2012 ( $4^{\text {th }}$ cut $)$ were plotted according to the number of days after planting/cutting, from which they obtained a polynomial adjustment for the regression equation (Figure 3).

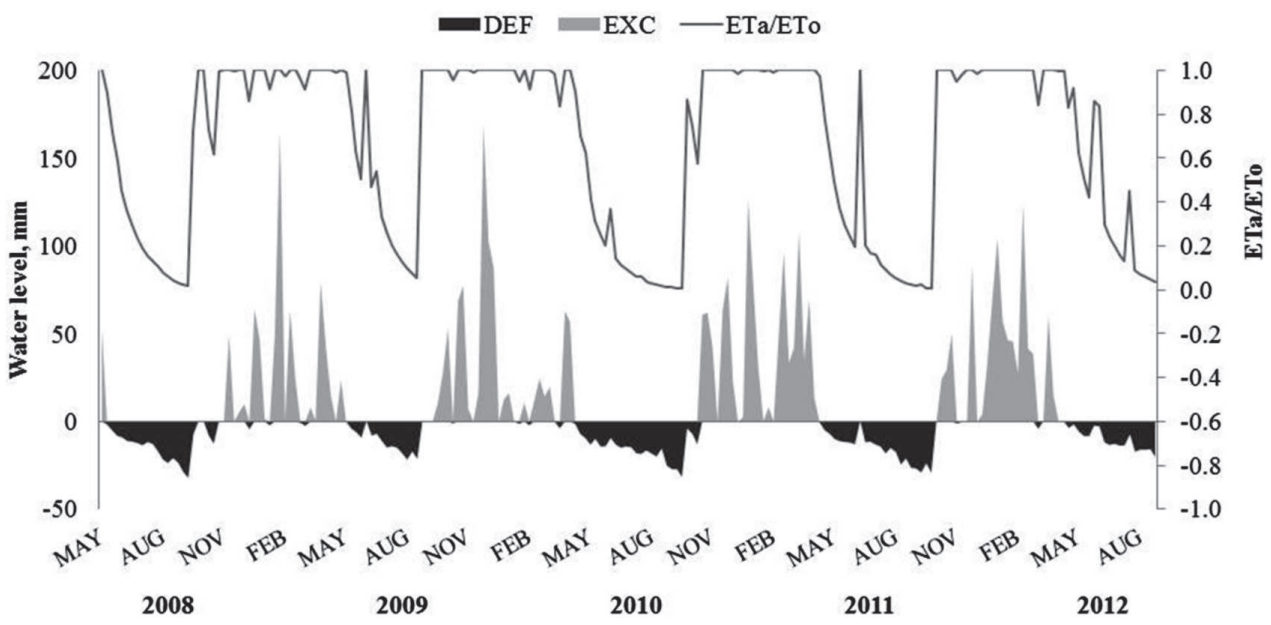

Figure 2: Water surplus (EXC), water deficit (DEF) and ratio between actual evapotranspiration and potential evapotranspiration $(\mathrm{ETa} / \mathrm{ETo})$ of the water balance performed from the values obtained in the experimental area in relation to the analized period. Santo Antônio de Goiás, state of Goiás.
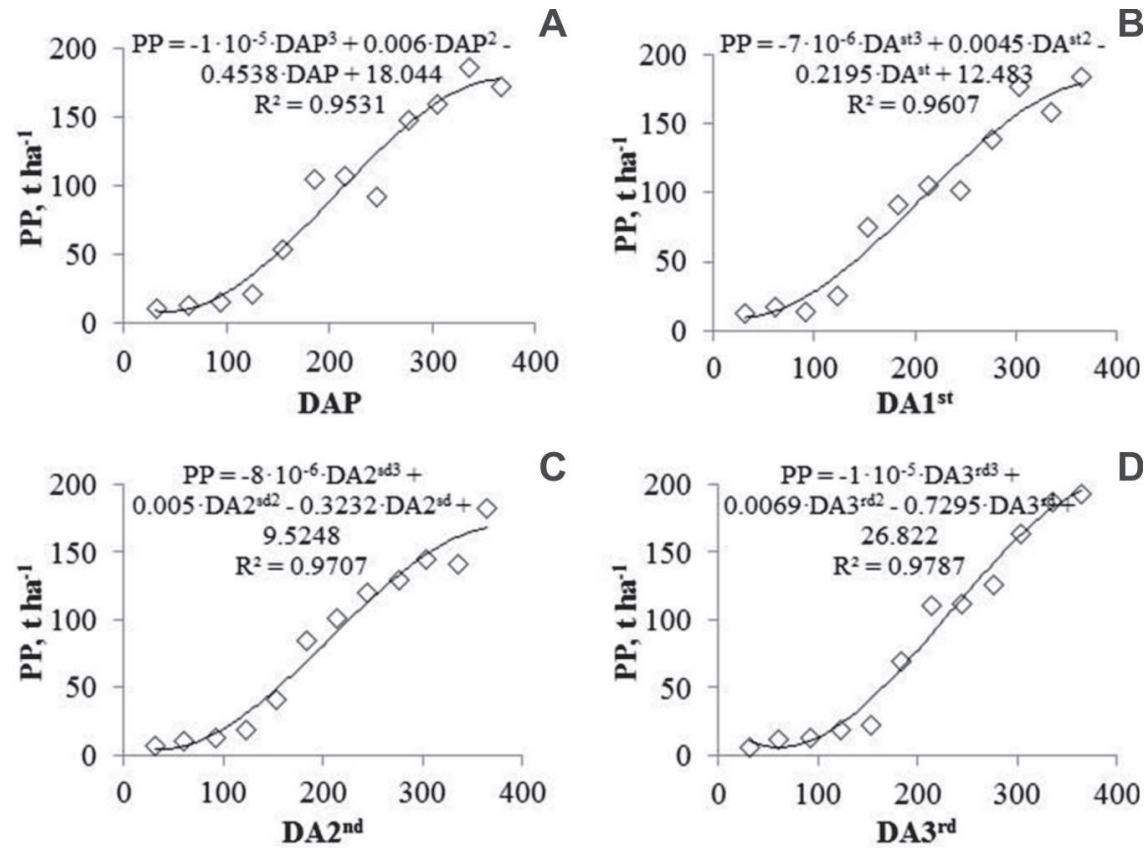

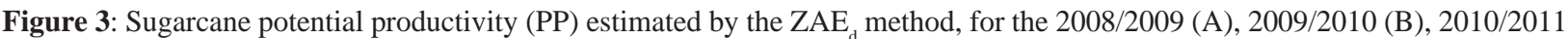
(C) and 2011/2012 (D) crops, according to the days after planting (DAP), days after the first cut (DA1 $1^{\text {st }}$ ), days after the second cut $\left(\mathrm{DA} 2^{\text {nd }}\right)$ and days after the third cut $\left(\mathrm{DA} 3^{\text {rd }}\right)$. Santo Antônio de Goiás, state of Goiás. 
The third-order polynomial curve shows an inflection point which mathematically reflects the change in the direction of the graph's concavity. This value is obtained by making the second derivative of the function belonging to the curve $f^{\prime \prime}(t)$ and then $f^{\prime}(t)=0$. In this case, the inflection point indicates the moment at which the instantaneous rate of potential productivity changes, showing an increase or a fall.

In the 2008/2009 harvest, the curve inflection occurs 200 days after planting (DAP), which is the second fortnight of November. The productivity rate of the crop until inflection was $0.53 \mathrm{tha}^{-1} \mathrm{day}^{-1}$, after which the rate decreased to $0.43 \mathrm{t} \mathrm{ha}^{-1}$ day $^{-1}$. Although the $200 \mathrm{DAP}$ of the sugarcane coincides with the beginning of the rainy season, specifically in this crop-year, the volume of rain was not sufficient to avoid the water stress of the crop, as it can be observed in the ETa/ETo curve, where constant

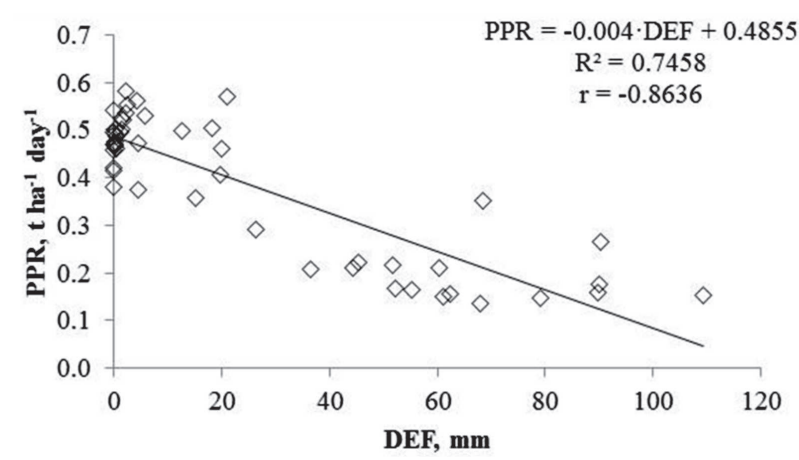

Figure 4: Sugarcane potential productivity rate (PPR) for all crops (that is, 2008/2009, 2009/2010, 2010/2011 and 2011/2012) according to the water deficit (DEF). Santo Antônio de Goiás, state of Goiás. values equal to 1.0 are not observed for the months from November to March (Figure 2).

The 2009/2010 harvest presented an inflection point on day 214 after the first cut. The 2010/2011 harvest had the inflection point 208 days after the second cut, while in the 2011/2012 harvest, this occurred 230 days after the third cut. Their productivity rates after the referred point showed an increase in relation to the rates obtained before that point, being these values, before and after the inflection point, of 0.51 and $0.52 ; 0.51$ and $0.54 ; 0.50$ and $0.68 \mathrm{t} \mathrm{ha}^{-1} \mathrm{day}^{-1}$, respectively for each crop previously mentioned. For the 2009/2010 and 2010/2011 harvests, the inflection point occurred in November, while in the 2011/ 2012 crop this inflection was observed in December.

This increase in the productivity rate is due to the beginning of the rainy season, which presented satisfactory volume of rain in these harvests, which provided water availability in the soil and met the crop evapotranspiratory demand, resulting in $\mathrm{ETa} / \mathrm{ETo}=1.0$, in almost all rainy season (Figure 2).

These results are evidenced by the negative correlation ( $r=-0.8636, \alpha=0.05$ ) found between the Potential Productivity Rate (PPR) and the Water Deficit (DEF) that occurred all over the study period (Figure 4 ). This result confirms that the occurrence of water deficit contributes to the decrease of potential productivity in a linear trend $\left(\mathrm{R}^{2}=0.7458\right)$

According to Rampino et al. (2006), any other stress (mechanical, thermal, etc.) negatively affects plant productivity as water stress. Water availability is the main cause of the variation of the interannual rates of sugarcane productivity, and its reductions are mainly attributed to
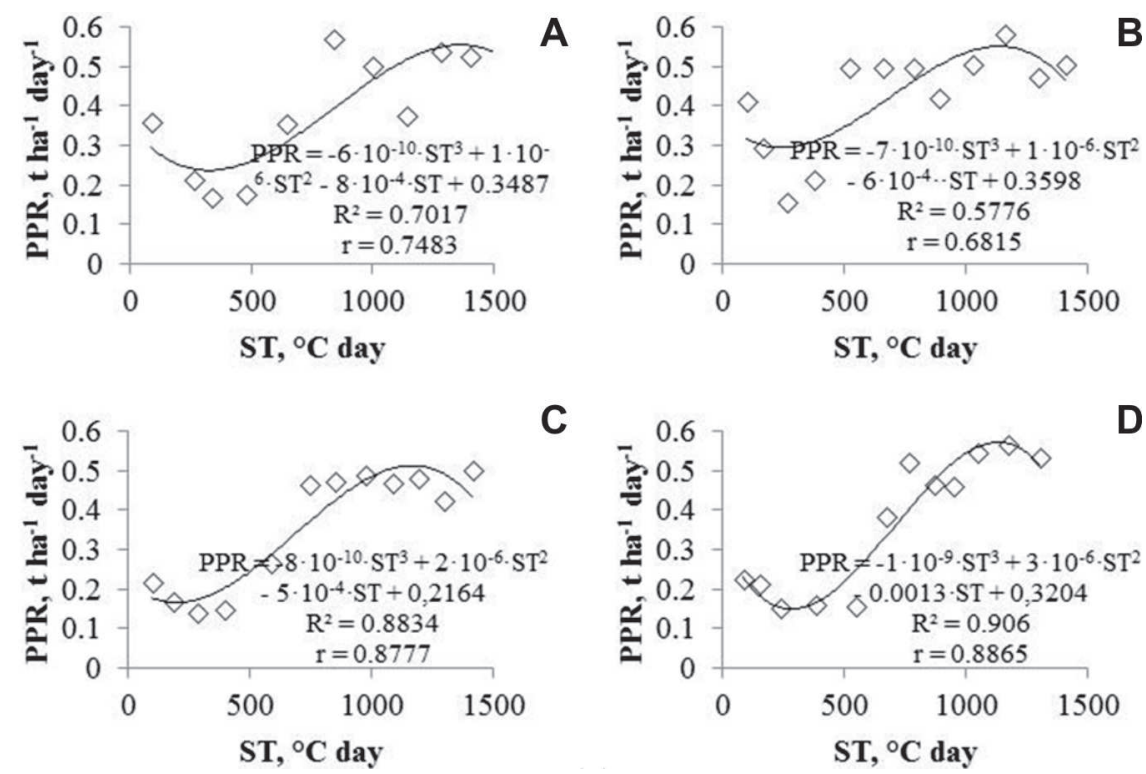

Figure 5: Sugarcane potential productivity rate (PPR) for the 2008/2009 (A), 2009/2010 (B), 2010/2011 (C) and 2011/2012 (D) crops, as a function of the thermal sum (ST). Santo Antônio de Goiás, Goiás state. 
the poor rainfall distribution. Inman-Bamber (2004) observed a reduction of about $35 \%$ in the biomass of young sugarcane plants due to the water restriction in a period of high evaporative demand.

Temperature is another climatic factor that directly interferes with the final production of sugarcane. The Thermal Sum (ST) was positively correlated with PPR in all harvests under study (Figure 5), confirming that the temperature significantly influenced the amount of sugarcane dry mass. According to Petek et al. (2009), in studies of climatic influence on crop growth, the concepts of water availability and thermal sum in degree-days should be studied together.

For the sugarcane crop, the thermal sum is directly related to the leaf area index (Scarpari, 2007), which predicts high production of photosynthates that contribute to the production of dry matter; root growth (Van Antwerpen et al., 1993), which contributes to the accumulation of sucrose in the stalks; and the number of tillers (InmanBamber, 1994) which constitute the plant's own dry mass.

In all harvests under study, the potential productivity rate started its growth at around $500^{\circ} \mathrm{C}$-day and reached its peak at $1250{ }^{\circ} \mathrm{C}$-day, on average, stabilizing after that (Figure 5). By assuming that the tillers result from the final crop production, the tiler density is a direct response of the productivity, therefore, it is possible to compare the results presented here with those obtained by InmanBamber (1994), who correlated the thermal sum with the beginning of tillering. In this study, the tillering was maximum at $500{ }^{\circ} \mathrm{C}$-day and the density of tillers was constant after $2000^{\circ} \mathrm{C}$-day, however, these values change for different varieties of sugarcane.

\section{CONCLUSIONS}

For cane-plant, ZAE is the model that best estimated stalk yield, considering the water deficit.

The model proposed by Scarpari (2002), corrected as a function of the productivity loss observed for the state of Goiás, can be used to estimate the productivity of ratoon cane.

Sugarcane productivity rate decreases linearly as water deficit increases.

The increase in the thermal sum contributes to the growth of the productivity rate up to $1250{ }^{\circ} \mathrm{C}$-day, approximately. After this moment, the rate of productivity becomes constant.

\section{REFERENCES}

Barbieri V, Bacchi OOS \& Villa Nova NA (1979) Análise do fator temperatura média do ar no desenvolvimento da cana-de-açúcar (Saccharum spp.). In: Congresso Brasileiro de Agrometeorologia, Mossoró. Anais, SBAgro. p.192-197.
Barbieri V \& Silva FC (2008) Adequação do Método da Zona Agroecológica (FAO) para estimativa do acúmulo mensal potencial de matéria seca da cana-de-açúcar (Saccharum spp.) e da produtividade agrícola para diferentes condições climáticas. STAB, 26:47-50.

Batista ELS, Zolnier S, Ribeiro A, Lyra GB, Silva TGF \& Boehringer D (2015) Avaliação do efeito do estresse hídrico no crescimento de cultivares de cana-de-açúcar usando um sistema automático de fertirrigação. Engenharia Agrícola, 35:215-229.

Blain GC, Kayano MT, Sentelhas PC \& Lulu J (2009) Variabilidade sazonal da evapotranspiração relativa em Campinas (SP): caracterização climática e análise de tendências. Bragantia, 68:545-553.

Carvalho GL (2009) Eficiência da produção agrícola de cana-deaçúcar no Estado de São Paulo entre as safras 1990/1991 e 2005/2006. Dissertação de Mestrado. Escola Superior de Agricultura "Luiz de Queiroz", Piracicaba. 120p.

Conab - Companhia Nacional de Abastecimento (2014) Perfil do setor do açúcar e do álcool no Brasil. Available at: <http:// www.conab.gov.br/conteudos.php?a=539\&t=2\&Pagina objcmsconteudos=3\#A_objcmsconteudos $>$. Accessed on: October $14^{\text {th }}, 2014$.

Cruz PG, Santos PM, Pezzopane JRM, Oliveira PPA \& Araujo LC (2011) Modelos empíricos para estimar o acúmulo de matéria seca de capim-marandu com variáveis agrometeorológicas. Pesquisa Agropecuária Brasileira, 46:675-681.

Cuadra SV, Costa MH, Kucharik CJ, Rocha HR, Tatsch JD, InmanBarber NG, Rocha RP, Leite CC \& Cabral OMR (2012) A biophysical model of sugarcane growth. Global Change Biology, $4: 36-48$.

Doorenbos J \& Kassam AH (1979) Yield response to water. Rome, FAO. 172p. (Irrigation and Drainage Paper, 33).

Gouvêa JRF (2008) Mudanças Climáticas e a expectativa de impactos na cultura de cana-de-açúcar na Região de Piracicaba-SP. Dissertação de Mestrado. Escola Superior de Agricultura "Luiz de Queiroz", Piracicaba. 98p.

Gouvêa JRF, Sentelhas PC, Gazzola ST \& Santos MC (2009) Climate changes and technological advances: Impacts on sugarcane productivity in tropical Southern Brazil. Scientia Agricola, 66:593-605.

Inman-Bamber NG (1994) Temperature and seasonal effects on canopy development and light interception of sugarcane. Field Crops Research, 36:41-51.

Inman-Bamber NG (2004) Sugarcane water stress criteria for irrigation and drying off. Field Crops Research, 89:107-122.

Marin FR, Lopes-Assad ML, Assad ED, Vian CE \& Santos MC (2008) Sugarcane crop efficiency in two growing seasons in São Paulo State, Brazil. Pesquisa Agropecuária Brasileira, 43:14491455 .

Moraes AVC, Camargo MBP, Mascarenhas HAA, Miranda MAC \& Pereira JCVNA (1998) Teste e análise de modelos agrometeorológicos de estimativa de produtividade para a cultura da soja na região de Ribeirão Preto. Bragantia, 57:393406.

Oliveira RA, Santos RS, Ribeiro A, Zolnier S \& Barbosa MHP (2012) Estimativa da produtividade da cana-de-açúcar para as principais regiões produtoras de Minas Gerais usando-se o método ZAE. Revista Brasileira de Engenharia Agrícola e Ambiental, 16:549-557.

Petek MR, Sera T \& Fonseca IC (2009) Exigências climáticas para o desenvolvimento e maturação dos frutos de cultivares de Coffea arabica. Bragantia, 68:169-181. 
Pezzopane JRM, Santos PM, Mendonça FC, Araujo LC \& Cruz PG (2012) Dry matter production of Tanzania grass as a function of agrometeorological variables. Pesquisa Agropecuária Brasileira, 47:471-477.

Rao CM, Kumar MV \& Reddy LK (2005) Management of sugarcane clones under limited moisture situations (drought) at formative stage. Indian Sugar, 54:949-953.

Rampino P, Pataleo S, Gerardi C, Mita G \& Perrotta C (2006) Drought stress response in wheat: physiological and molecular analysis of resistant and sensitive genotypes. Plant Cell Environ, 29:2143-2152.

Rodrigues JD (1995) Fisiologia da cana-de-açúcar. Botucatu, Unesp. $99 \mathrm{p}$.

Rossetti L (2001) Zoneamento agrícola em aplicação de crédito e seguridade rural no Brasil: aspectos atuais e de política agrícola. Revista Brasileira de Agrometereologia, 9:386-399.

Scarpari MS (2002) Modelos para a previsão da produtividade da cana-de-açúcar (Saccharum spp.) através de parâmetros climáticos. Dissertação de Mestrado. Escola Superior de Agricultura "Luiz de Queiroz", Piracicaba. 79p.
Scarpari MS \& Beauclair EGF (2004) Sugarcane maturity estimation through edaphic-climatic parameters. Scientia Agricola, 61:486491.

Scarpari MS (2007) PREDPOL: um modelo de previsão da maturação da cana-de-açúcar visando planejamento otimizado. Tese de Doutorado. Escola Superior de Agricultura "Luiz de Queiroz", Piracicaba.120p.

Teramoto ER (2003) Avaliação e aplicação de modelos de estimativa de produção de cana-de-açúcar (Saccharum spp.) baseados em parâmetros do solo e do clima. Tese de Doutorado. Escola Superior de Agricultura "Luiz de Queiroz", Piracicaba. 86p.

Thornthwaite CW (1948) Na approach toward a rational classification of climate. Geographical Review, 38:55-94.

Thornthwaite CW \& Mather JR (1955) The water balance. New Jersey, Drexel Institute of Technology.104p.

Van Antwerpen R, Meyer JH \& Inman-Bamber NG (1993) Cane root development and crop modelling. Proceedings of the South African Sugar Technologists' Association, 67:73-77. 